\title{
Polybrominated diphenyl ethers (PBDEs) in sediment and fish tissues from Lake Chaohu, central eastern China
}

\author{
Suwen Yang ${ }^{1}$, Qiang Fu ${ }^{2 *}$, Man Teng ${ }^{2}$, Jing Yang ${ }^{2}$ \\ ${ }^{1}$ Academy of Environmental Sciences, China \\ State Key Laboratory of Environmental Criteria and Risk Assessment \\ ${ }^{2}$ Environmental Monitoring Quality Control Department of China National Environmental Monitoring Center, China \\ *Corresponding author's e-mail: fuqiang@cnemc.cn
}

Keywords: polybrominated diphenyl ethers, exposure level, sediment, tissue distribution, Lake Chaohu.

\begin{abstract}
Polybrominated diphenyl ethers (PBDEs) levels in environmental media have increased over the last 20-25 years in the world. In aquatic environments PBDEs were found to be accumulated along food chain and Endocrine disruptors toxicity. In this study PBDEs were investigated in sediment and fish tissues from Lake Chaohu in central eastern China. There were 10 PBDEs congeners detected out of all 41 PBDEs. BDE-47 was of the highest with $5.17 \mathrm{ng} / \mathrm{g}$ in sediment and $58.47 \mathrm{ng} / \mathrm{g}$ in fish. PBDEs were evenly distributed across the surface sediment in the whole lake. It implied that the main source of PBDEs may not be an inflow river like Nanfei. Tissue distribution patterns of PBDEs in four fish species were in the order of BDE-47 > BDE-99 > BDE-100 $>$ BDE-66 > BDE-138 > BDE-183 > BDE-154 > BDE-153. Octa- and deca-BDEs were below the detection limit. The concentrations of all PBDE congeners were higher in gills, livers, and kidneys than those in muscles and adipose tissue. Furthermore, PBDEs in different tissues had some different distribution patterns with fish size. Those discrepancies appeared to be correlated with the PBDEs pollution fluxes varying with the change of the year and their metabolism divergences in fish tissues.
\end{abstract}

\section{Introduction}

Polybrominated diphenyl ethers (PBDEs) are widely utilized fire retardants embedded in textiles, plastics, electrical components, paints, foam, rubber, and other casing materials (Petreas et al. 2011). Commercial production began in the 1970s and PBDEs levels in various environmental media have rapidly increased over the last $20-25$ years (Tanabe et al. 2008). It is highly concerned due to their toxicity and Endocrine disruptors (Karpeta et al. 2011, Liu et al. 2012). These reports prompted governments all over the world to initiate studies to generate more information regarding their significance in order to take necessary regulatory actions (Kemmlein et al. 2003). For example, penta- and octa-BDEs have been banned from all products in the EU-market from August 2004, as well as in 10 states of the U.S.A. (BSEF 2004), they are still used in China and remain as ubiquitous long-term threats in the environment. Fish consumption has been associated with higher PBDE levels in some human population surveys (Sjödin et al. 2000). Food and water contribute $18 \%$ of the total PBDE ingestion (Lorber 2007). Human beings will continue to be exposed to these chemicals despite those increased regulation mentioned before (Frederiksen et al. 2009).

Concentrations and distributions of PBDEs in the environment were well documented in North America (Dallaire et al. 2009), Europe (Jaraczewska et al. 2006, Roosens et al. 2010), Australia (Besis and Samara 2012) and Asia (Hong et al. 2010). Yet, there is little information about the exposure levels of PBDEs in Chinese lakes (Zhou et al. 2012). It is well known that China has several brominated flame retardants manufacturing plants that mainly produce PBDEs, and they are mostly located in eastern China, near to Lake Chaohu. Therefore, it is important to explore the exposure level of PBDEs in Lake Chaohu to cognize its ecological toxicity risk. The aim of this study was to determine environmental exposure levels of PBDEs and congener-specific deposition profiles in sediment and fish species of Lake Chaohu. It is the fifth largest lake in China which is the most important source of drinking water for five provinces in China. Sediments and fish have played an important role in the distribution and fate of PBDEs and aquatic environments health. Fish pollution investigation can provide information on the transformation and bioaccumulation of PBDE to human being. Correspondingly comprehensive survey of PBDE contamination aimed at Lake Chaohu is urgently needed. Tissues and organs such as adipose tissue, liver, muscle, gill, and kidney of four fish species in Lake Chaohu and forty-one PBDEs congeners were analyzed in this study. The results can provide useful information about the exposure levels of PBDEs and further evaluation for potential ecological risk in Chinese great lakes. 


\section{Materials and methods}

\section{Samples collection}

Sediment and fish samples were collected from Lake Chaohu which is located in Anhui Province, eastern China and within the Yangtze river system. Sediment and fish samples were obtained in July and November 2009. Sample sites recorded by GPS are shown in Fig. 1 where sediment samples were obtained from all four sites, fish samples from No. 3 site.

Surface sediment core samples $(0-10 \mathrm{~cm})$ were taken from four sites of Lake Chaohu by a Beeker Sampler with a $30 \mathrm{~cm}$ LX $5 \mathrm{~cm}$ DI plexiglas cylinder tube. Fish samples including Cyprinus carpio, Culter alburnus, Hypophthalmichthys molitrix, Aristichthys nobilis which are the main economy fish species in Chaohu Lake were captured in the center of western Lake Chaohu (Table 1). Adipose tissue, muscles, gills, liver and kidney of fishes were washed first. Sediment and fish samples were preserved in $-4^{\circ} \mathrm{C}$ potable iceboxes in the field. Then they were taken into laboratory to freeze-dry, grind, and sieve for further analysis.

\section{Chemicals and reagents}

A PBDE analytical standard solution was purchased from AccuStandard, Inc. (New Haven U.S.A.). It contained 39 PBDE congeners (purity from $95.2 \%$ to $100 \%$, concentrations ranging from $98.0-251.3 \mathrm{ng} / \mathrm{mL}$ ), including 3 mono-BDEs (BDE 1, 2, and 3 ), 7 di-BDEs (BDE 7, 8, 10, 11, 12, 13 and 15), 8 tri-BDEs (BDE 17, 25, 28, 30, 32, 33, 35 and 37), 6 tetra-BDEs (BDE 47, 49, 66, 71, 75 and 77), 7 penta-BDEs
(BDE 85, 99, 100, 116, 118, 119 and 126), 5 hexa-BDEs (BDE 138, 153, 154, 155 and 166), 3 hepta-BDEs (BDE 181, 183 and 190$)$ at $100-250 \mathrm{ng} \cdot \mathrm{mL}^{-1}$. The other two PBDE standard octa-BDE (BDE 197) and deca-BDE (BDE 209) was solid powder, purity $>97.5 \%$, purchased from China Ji'nan Taixing Fine Chemical Co., Ltd. Internal standard ${ }^{13} \mathrm{C}$-BDE99 as the recovery rate indicator and ${ }^{13} \mathrm{C}-\mathrm{PCB}-141$ as instrument internal standard were obtained from Cambridge Isotope Laboratory, Andover, USA. Chromatographic grade solvents, methanol, hexane, dichloromethane and sulfuric acid, were purchased from Merck (Darmstadt, Germany). Diatomite was obtained from Beijing Nuoxin Shengyuan Ltd, China. To avoid human exposure, all standards and solvents were manipulated under a hood and using gloves, glasses and clean overalls. Extraction and clean up procedures were also performed under a hood.

\section{Sample extraction and clean-up}

$5.00 \mathrm{~g}$ ground samples of fish and sediment, adding internal standard ${ }^{13} \mathrm{C}$-BDE-99, were mixed with $10.00 \mathrm{~g}$ diatomite and extracted with an ASE (Accelerated Solvent Extraction) instrument using $200 \mathrm{ml}$ hexane/dichloromethane $(1: 1, \mathrm{v} / \mathrm{v})$ 3 times. The extraction solutions of samples were concentrated to 3-5 ml, eluted with $150 \mathrm{ml}$ hexane/dichloromethane (1:1, $\mathrm{v} / \mathrm{v}$ ) in multilayer silica gel columns (inner-diameter $2 \mathrm{~cm}$, length $25 \mathrm{~cm}$ ) filled from the bottom with $2 \mathrm{~g} \mathrm{AgNO}_{3}$ silica, $1 \mathrm{~g}$ of activated silica gel, $3 \mathrm{~g}$ of silica/ $\mathrm{NaOH}, 1 \mathrm{~g}$ of activated silica gel, $8 \mathrm{~g}$ of silica/ $\mathrm{H}_{2} \mathrm{SO}_{4} 44 \%$ (w/w), $4 \mathrm{~g}$ of silica/ $\mathrm{H}_{2} \mathrm{SO}_{4} 22 \%$ $(\mathrm{w} / \mathrm{w})$, and $1 \mathrm{~g}$ of activated silica topped with $2 \mathrm{~cm}$ of $\mathrm{Na}_{2} \mathrm{SO}_{4}$. After concentration the eluent was cleaned in a florisil column

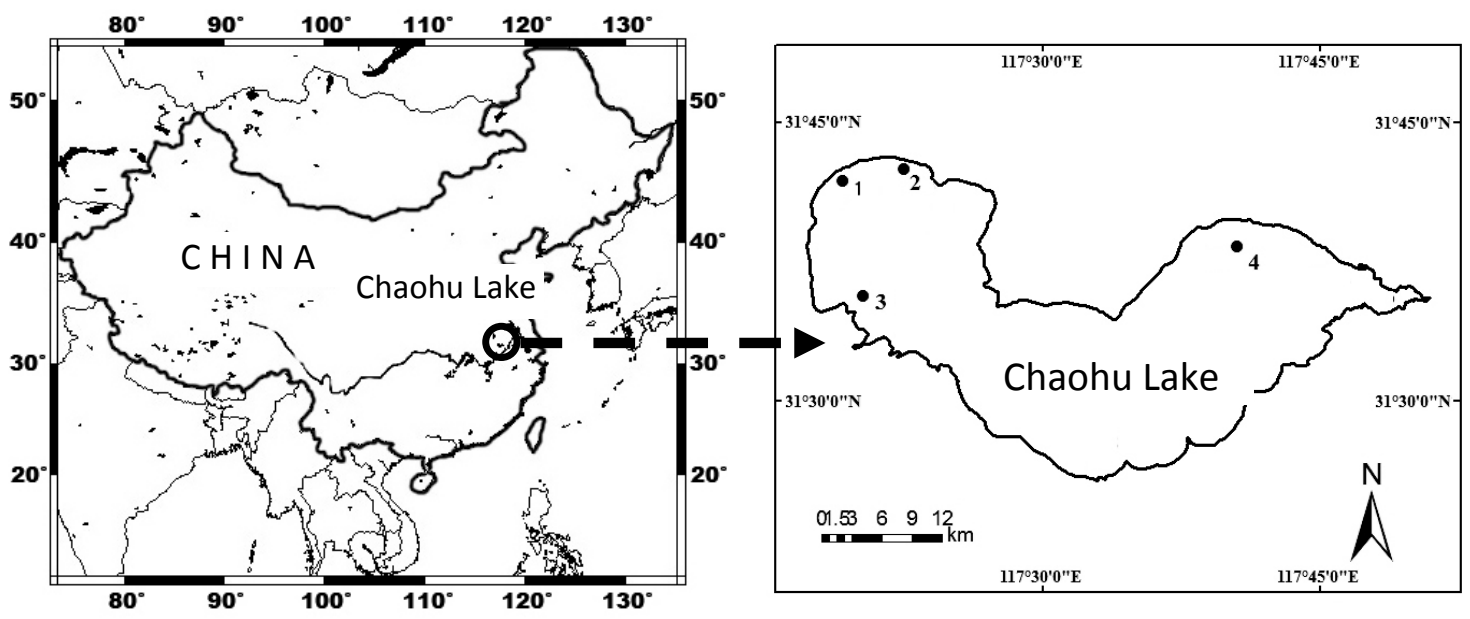

Fig. 1. Map of the sampling sites of Lake Chaohu in China

Table 1. Details of freshwater fishes from Lake Chaohu

\begin{tabular}{|l|c|c|c|c|}
\hline \multicolumn{1}{|c|}{ Common name } & Scientific name & $\begin{array}{c}\text { Number } \\
\text { of samples }\end{array}$ & $\begin{array}{c}\text { Weight } \\
(\mathrm{g})\end{array}$ & $\begin{array}{c}\text { Length } \\
(\mathrm{cm})\end{array}$ \\
\hline Common carp & Cyprinus carpio & 5 & $800 \pm 200$ & $26 \pm 5$ \\
\hline Topmouth culter & Culter alburnus & 4 & $600 \pm 400$ & $20 \pm 5$ \\
\hline Silver carp & $\begin{array}{c}\text { Hypophthalmichthys } \\
\text { molitrix }\end{array}$ & 5 & $2125 \pm 875$ & $36 \pm 6$ \\
\hline Big-head carp & Aristichthys nobilis & 3 & $1875 \pm 375$ & $33 \pm 3$ \\
\hline
\end{tabular}


filled from the bottom with $2 \mathrm{~g}$ of glass cotton, $5 \mathrm{~g}$ of florisil, and topped with $2 \mathrm{~cm}$ of $\mathrm{Na}_{2} \mathrm{SO}_{4} 100 \mathrm{ml}$ hexane eluted florisil column. The eluent was collected and concentrated to $20 \mu \mathrm{l}$, adding internal standard ${ }^{13} \mathrm{C}-\mathrm{PCB}-141$ for $\mathrm{GC} / \mathrm{MS}$ analysis.

\section{Instrumental analysis}

GC/MS analysis of PBDEs was performed following the procedure described by Zhao et al. (2010) with slight modification. PBDEs congeners were detected by GC/MS on Agilent 5973 mass spectrometer (Agilent Technology Company, Wilmington, USA) equipped with a 6890 gas chromatograph. Gas chromatograph with the chromatographic column was DB-5 MS (American Agilent company), $15 \mathrm{~m} \times$ $25 \mu \mathrm{m} \times 0.25 \mu \mathrm{m}$. Mass spectrometry with negative chemical ionization mass spectrometry (MS-NCI) in the selected ion mode (SIM), with high pure helium as carrier gas, methane as reactant gas, ion source temperature $150^{\circ} \mathrm{C}$, quadropole temperature $150^{\circ} \mathrm{C}$. High voltage pulse splitless inlet: inlet temperature was $265^{\circ} \mathrm{C}$, interface temperature $-300^{\circ} \mathrm{C}$, carrier gas flow rate was $1.5 \mathrm{~mL} / \mathrm{min}, 6 \mathrm{~min}$ solvent delay. Temperature program: starting temperature $80^{\circ} \mathrm{C}(1 \mathrm{~min})$, with $10^{\circ} \mathrm{C} / \mathrm{min}$ up to $200^{\circ} \mathrm{C}$, with $20^{\circ} \mathrm{C}$ up to $300^{\circ} \mathrm{C}(15 \mathrm{~min})$. The injection volume was $1 \mu \mathrm{L}$. Retention time applied for qualitative and external standard method was used for quantitative analyses. Scanning ion: mono- to hepta-BDE for $\mathrm{m} / \mathrm{z}=79,81$, deca-BDE for $\mathrm{m} / \mathrm{z}=486.7,488.7,{ }^{13} \mathrm{C}-\mathrm{PCB} 141$ for $\mathrm{m} / \mathrm{z}=372,374$.

\section{Quality assurance}

Instrumental quality control was done by regular injection of solvent blanks and standard solution. Procedural blanks were run in parallel. The concentrations of PBDEs in dosed groups were corrected by subtraction of average procedural blank value and that of the control groups. To evaluate the method performance using ${ }^{13} \mathrm{C}$-BDE 99 as internal standard quantification for extracting and cleaning course, ${ }^{13} \mathrm{C}-\mathrm{PCB}-141$ was used as internal standard quantification for instrument analysis. The average recovery rate was $76 \%$ and RSD (Relative standard deviation) was less than 15\%.

\section{Statistical analysis}

Statistical treatment of the obtained results was performed with the SPSS (Statistical Product and Service Solutions) 11.0 for Windows. Spearman rank correlation was used to examine the strength of associations between parameters. Probability values less than 0.05 were considered as statistically significant.

\section{Results and discussion}

\section{Spatio-temporal distribution of PBDEs in sediment}

PBDEs were detected in Lake Chaohu sediment at all four sample sites in July and November 2009. Of the 41 PBDE congeners analyzed, 10 were present in all sediment samples (Fig. 2), indicating that PBDEs are widespread in the lake. Octa-BDE and deca-BDE were not detected. Mean concentration of $\Sigma$ PBDEs in sediment in those two months was $33.01 \mathrm{ng} / \mathrm{g}$ and $32.76 \mathrm{ng} / \mathrm{g}$ respectively. Therefore, it is worthwhile to note that the samples collected between two months did not have significant difference. Mean concentration order of the 10 PBDE congeners based on the two months' average value was: BDE-47 (18.64\%), -154 (13.06\%), -183 $(11.99 \%),-153(10.19 \%),-138(9.70 \%),-99(8.05 \%),-85$
(7.82\%), -66 (7.78\%), -100 (7.12\%), -28 (5.65\%). BDE-47 was the predominant congener with the concentration of $6.13 \mathrm{ng} / \mathrm{g}$. Apart from BDE-47, BDE-154, BDE-183, BDE-153, and BDE-138, the concentrations of other PBDE congeners were less than $3 \mathrm{ng} / \mathrm{g}$. Interestingly, the sum of hexa- and hepta-BDE in sediment from the present study accounted for $44.94 \%$ of the total PBDEs. This relative abundance of higher brominated congeners was quite different from previous observations of Yangtze River in China (Shen et al. 2006), where the higher brominated congeners only accounted for mean $15 \%$ of the total. The reason is probably due to different production of PBDE congeners using different watersheds. Also there was no significant difference between the sample sites. This revealed that the source of PBDEs may be not inflow rivers, such as the Nanfei and Shiwuli, which are main inflow rivers of Lake Chaohu from northwest and are heavily polluted by municipal sewage. Another source may be air deposition through long distance transportation (Hale et al. 2006). Long distance transportation is considered to be the main pollution source for non-polluted area (Mai et al. 2005, Chen et al. 2013 b) in Dongguan area of southeast China. By contrast, the concentration of $\sum$ PBDE in surface sediments of bay area around the Yellow Sea was far lower than those measured in the present study, such as $1.3 \mathrm{ng} / \mathrm{g}$ in Laizhou Bay (Jin et al. 2008), and $0.16 \mathrm{ng} / \mathrm{g}$ in the Bo Sea (Wang et al. 2009).

PBDE levels in lake, river and marine sediments varied from nanograms per gram of dry weight to micrograms per gram of dry weight, depending on the sampling locations, as reviewed by de Wit (2002) in Europe and North America, Zhou et al. (2012) in Asia, Law et al. (2008) in Europe, and Yogui and Sericano (2009) in USA. Heavily industrialized and populated areas are generally more contaminated where the highest value of $\sum$ PBDEs would reach $14000 \mathrm{ng} / \mathrm{g}$ (Eljarrat et al 2007) than remote areas where the concentration was generally not more than $1000 \mathrm{ng} / \mathrm{g}$ (Moon et al. 2012). In addition, the PBDE congeners order found in this study was BDE-47 > BDE-154 > BDE-183 > BDE-153 > BDE-138> BDE-99, just similar to the traditional distribution pattern (Law et al. 2008, Yogui and Sericano 2009), a large difference from the order for air: BDE-99 > BDE-153 > BDE-166 > BDE-154 $>$ BDE-49 > BDE-47 (Hale et al. 2006). That difference may be related to different degradation mode of PBDEs from air deposit to sediment decomposition.

\section{PBDEs distribution in organs and tissues of fish}

Mean $\Sigma$ PBDEs concentrations of four fish samples ranged from 120.65 to $129.77 \mathrm{ng} / \mathrm{g}$. There were no significant differences between fish species. PBDEs have been shown to be biomagnified in aquatic food chains, including those in remote Arctic (Kelly et al. 2008). Four fishes in this research belong to carnivorous and omnivorous species. No significant discrepancy of PBDEs distribution pattern of inter-species fishes was found. This result is in agreement with a previous research of Weijs (2009). $\Sigma$ PBDE distribution levels of fishes from Lake Chaohu was similar to that from Yangtze River in China (Xian et al. 2008) and Lake Canal in Belgium (140 ng/g) (Covaci et al. 2005), far lower than Hyco River in Virginia $(1,140 \mathrm{ng} / \mathrm{kg}$ for carp) (Hale et al. 2001) in USA, and far higher than that in eleven French lakes $(0.032 \pm 0.056 \mathrm{ng} / \mathrm{g}$ wet weight) (Blais et al. 2006), Liobregat River in Spain (43 ng/g) (Labandeira et al. 2007), and Syr Dam Lake in Turkey (44 ng/g) 


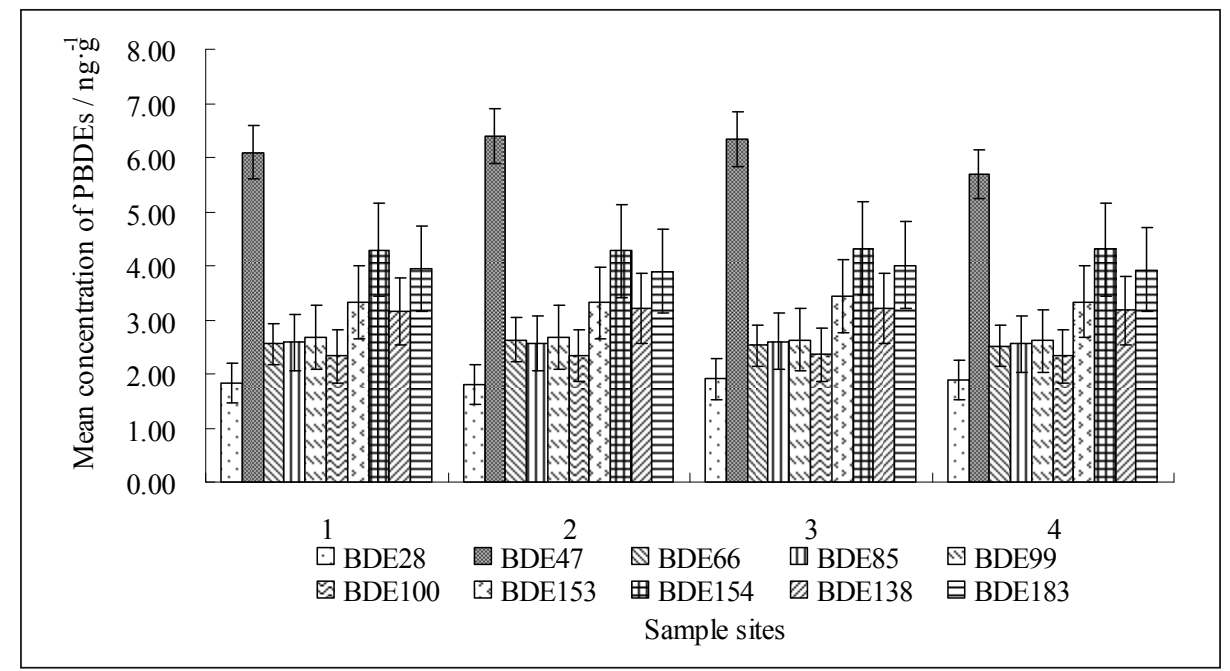

Fig. 2. Mean concentration of ten PBDE congeners of surface sediment in Chaohu Lake

(Erdgrul et al. 2005). $\Sigma$ PBDE concentration ranged from 6 to $43 \mathrm{ng} / \mathrm{g}$ lipid weight among fish species from Australia marine environment (Hermanussen et al. 2008). Therefore, the PBDEs concentrations were ordered as follows: Europe, Australia $\leq$ Asia $<$ North America. Mean levels in North American people and fish have been found to be up to 10 times higher than in European samples (Huwe et al. 2008), while in South America, e.g. in Brazil, PBDEs concentration was lower than the limit of quantification (Lavandier et al. 2013). The trend is most likely due to the heavier use of PBDEs in North America compared to other areas (Hites 2004).

BDE-47 was taken as an example to (Fig. 3) illustrate that concentrations of all PBDEs congeners analyzed in liver and kidney were significantly higher than those in muscle because of other PBDE congeners showing the same pattern in the present study. It was found that concentrations of PBDEs in adipose tissue were a bit lower than those in liver, kidney, and gill in this study. A similar study conducted by Huwe (2008) on rats exposed to PBDEs showed that the accumulation of these substances in adipose tissue and kidney contributed to almost the same percentage of total PBDEs. A reasonable explanation for the selective accumulation of these lipophilic contaminants in liver and kidney of these PBDE congeners was likely due to their special tissue which can specifically sorb PBDEs, and unique active hepatic accumulation process in liver (Xian et al. 2008) as well as renal reabsorption in kidney. Furthermore, in recent years, report showed that total PBDE content in the gulls was positively associated with protein but not lipid content when analyzed together with body composition (Verreault et al. 2007). Another interesting thing was that PBDEs concentrations in gill were also higher than those in muscle and adipose tissue at present study. This indicated that PBDEs can straightly enter the fish body through gill respiration (Guo et al. 2007). Another possible reason would be the microcilia of gill absorbing PBDEs. Little similar research has been performed with regard to the distribution in gill, and further study is needed.

Among all the 10 PBDE congeners detected in fish, the sum of tetra-BDE (BDE-47, 66) and penta-BDE (BDE-99, 100) accounted for $70 \%$ of total PBDEs. The order of mean PBDE congener concentrations was BDE-47 (46.66\%), -99 (8.71\%), $-100(7.37 \%),-66(7.28 \%),-138(6.11 \%),-183(5.30 \%)$, $-154(5.29 \%),-153(5.16 \%),-85(4.10 \%)$, and $-28(4.02 \%)$ (Fig. 4). The distribution pattern of PBDE congeners in this

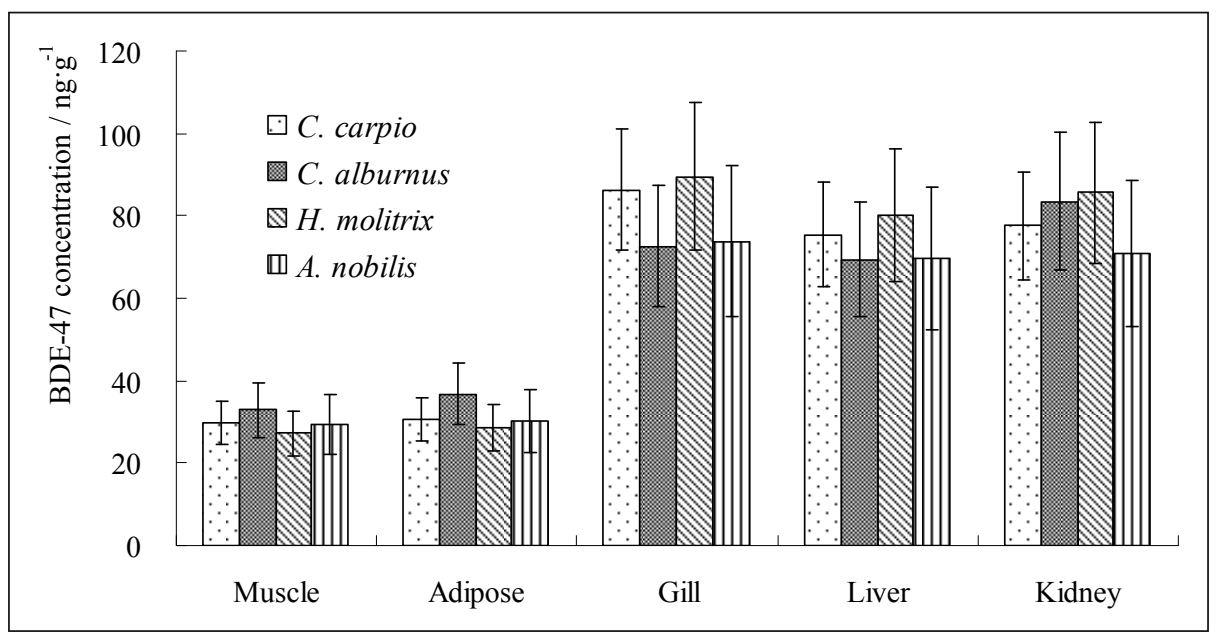

Fig. 3. Concentrations of BDE-47 in five tissues of four fishes in Chaohu Lake 
study was typical, and is similar to the pattern of most aquatic animals investigated from other lakes of the world (Binelli et al. 2008), except for Taiwan rivers where the order was BDE-47 > 154, 153>99 (Peng et al. 2007). These results are due to the greater use of octa-BDE rather than penta-BDE in Tai Wan than in China mainland and other countries. Not surprisingly, BDE-47 was the predominant congener found in the tissues. Its concentrations in gill, liver and kidney tissues ranged from 69.31 to $89.41 \mathrm{ng} / \mathrm{g}$ which was 2.5 -fold higher (Fig. 3) than that in muscle and adipose tissues ranging from 27.11 to $36.83 \mathrm{ng} / \mathrm{g}$. Those were higher than those in fishes from Yangtze river (Xian et al. 2008). Furthermore, BDE-47 concentration was also one order magnitude higher than that in the sediment of Lake Chaohu. The dominance of BDE-47 in fishes of the present study was consistent with the general pattern found in biota samples (Chen et al. 2013a). The reason for higher BDE-47 concentration may be due to its high assimilation efficiencies and due to the production of BDE 47 in fish tissues being a result of debromination of higher-brominated compounds (Stapleton et al. 2004a). The accumulation extent of another important congener BDE-99 in fish was in the second place just following BDE-47. Its distribution pattern and level were consistent with eel from Italy lagoon (Mariottini et al. 2008). But in some other previous reports, the BDE-99 contributed $<1 \%$ of total PBDEs (Xian et al. 2008; Xia et al., 2011).

The concentration of BDE-47 was 5.4 folds higher than that of BDE-99. This ratio was about 5 in European eel from Orbetello lagoon in Italy (Mariottini et al. 2008), close to that research. Marked differences in the ratios of BDE47 to BDE99 were observed among the examined biological species of the St. Lawrence Estuary food web. BDE47/99 ratios in some fish species such as rainbow smelts, American eels, American plaice and smooth flounders were much higher 22-75 than in other organisms, such as zooplankton 1 and shrimp 8.5 (Law et al. 2003). It seemed that the distribution pattern of BDE-47 and -99 was similar between freshwater and marine fishes, while BDE47/99 ratio may be influenced by trophic level. In most wildlife and human samples, the ratio of BDE-47 to BDE-99 is much higher than the ratio of these two congeners in Penta-BDE formulations. The average ratio in biotic sample is generally $3-6$, and in commercial products is $\leq 1$ (Huwe et al. 2007). One reason for the greater accumulation of BDE-47 relative to BDE-99 in biota tissues is the higher metabolism rate for BDE-99 (Huwe et al. 2008). At least 9.5 of the BDE 99 mass in the gut was debrominated to BDE-47 and assimilated in carp tissues (Stapleton et al. 2004b). The ratio of BEE-47 to other PBDEs was close to BDE-99 and remains constant among tissues indicating that BDE-47 is one of the most readily accumulated PBDEs.

Octa-BDE (BDE-197) and BDE-209 were not detected in this work. As a highly bioavailable congener, BDE-197 has not been included in most reports of PBDEs in biota, but is an apparent byproduct of anaerobic and photolytic (Stapleton et al. 2008) degradation of BDE-209. It was considered to be low bioavailability, only less than $0.5 \%$ to be absorbed into biota (Hardy et al. 2002). Therefore, BDE-209 was hard to detect unless there was a certain extent of accumulation level in biota tissues (He et al. 2012). A BDE-209 exposure experiment showed that no net accumulation of BDE 209 in carp tissues was observed (Stapleton et al. 2004c). However, seven apparent debrominated products of BDE 209 accumulated in whole fish and liver tissues over the exposure period. That is to say, debromination occurred in fish tissues may be another reason for no BDE-209 detection. No matter how, these results implied that no significant BDE-209 pollution existed surrounding Lake Chaohu, indicating that the commercial octaand deca-BDE formulations were not massively manufactured in that area. This situation was quite different from Zhujiang area in Southern China where electronic industry was highly developed. Detection rate of BDE-209 was $45.2 \%$ of total fish samples (Guo et al. 2007).

It is obvious that individual PBDEs have different pharmacokinetic properties and should not necessarily be considered as a sum of the total in this context. One reason for different distribution patterns may be the involvement of transport proteins necessitated by different molecular weight of PBDE congeners (Huwe et al. 2008, Chen et al. 2013a). Further investigations are needed to determine what role carrier proteins may play in the uptake, distribution, metabolism, and excretion of PBDEs in aquatic animal systems.

The distribution of different PBDE congener in tissues of four fishes displayed different pattern with the varieties of

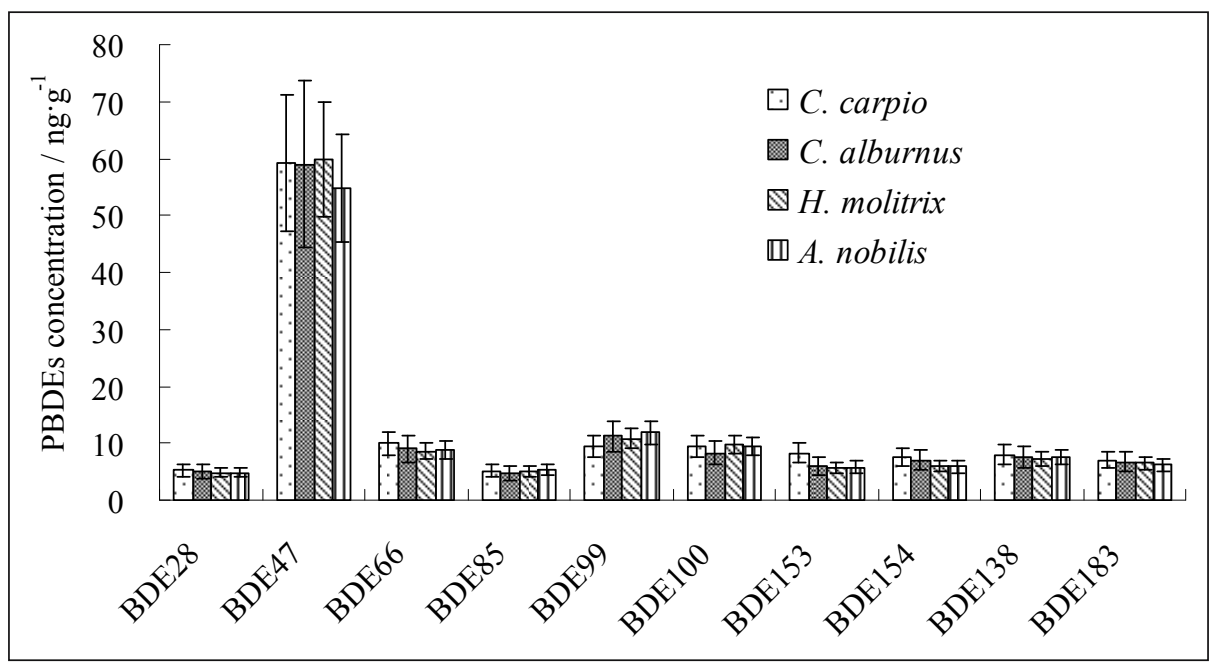

Fig. 4. Mean concentration of ten PBDE congeners of four fishes in Chaohu Lake 
(A)
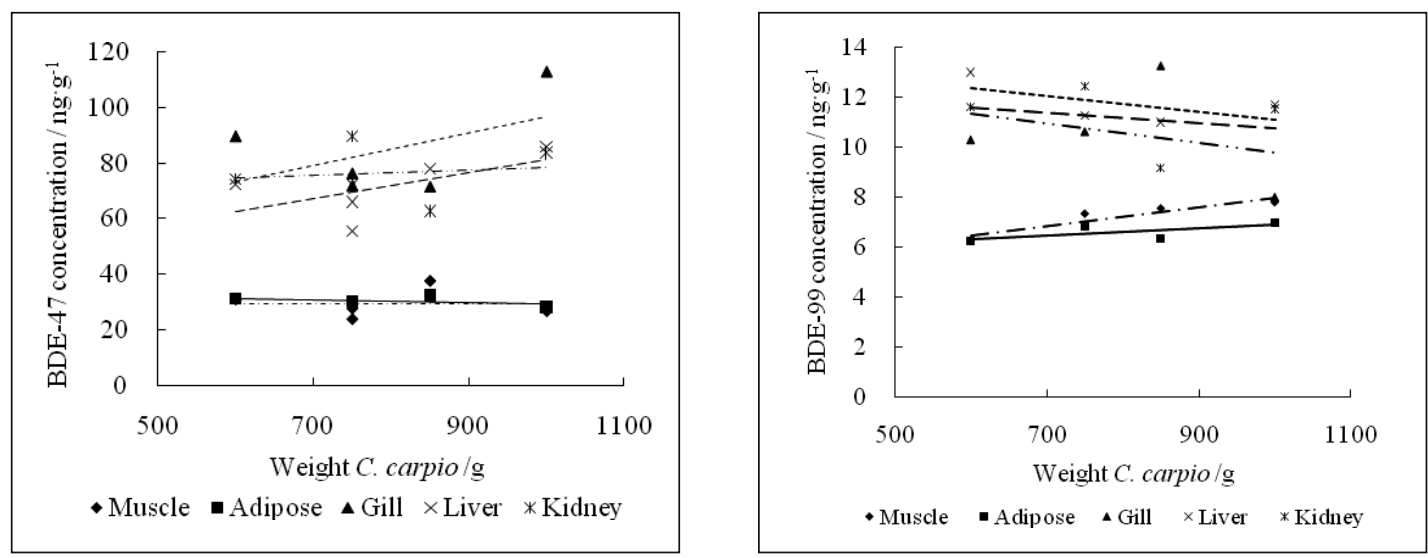

(B)
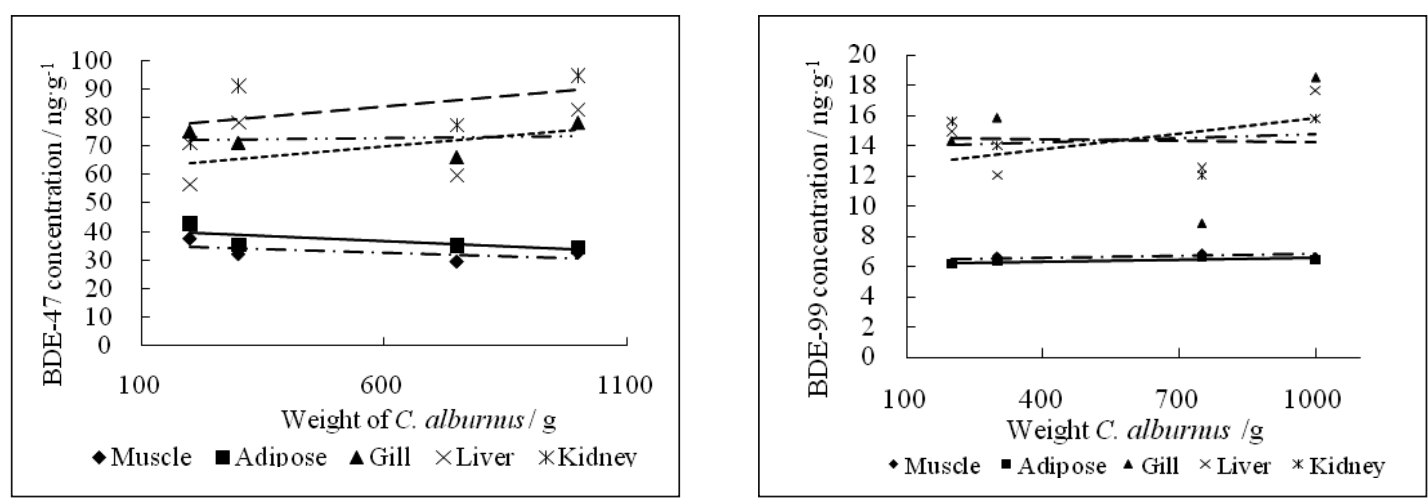

(C)
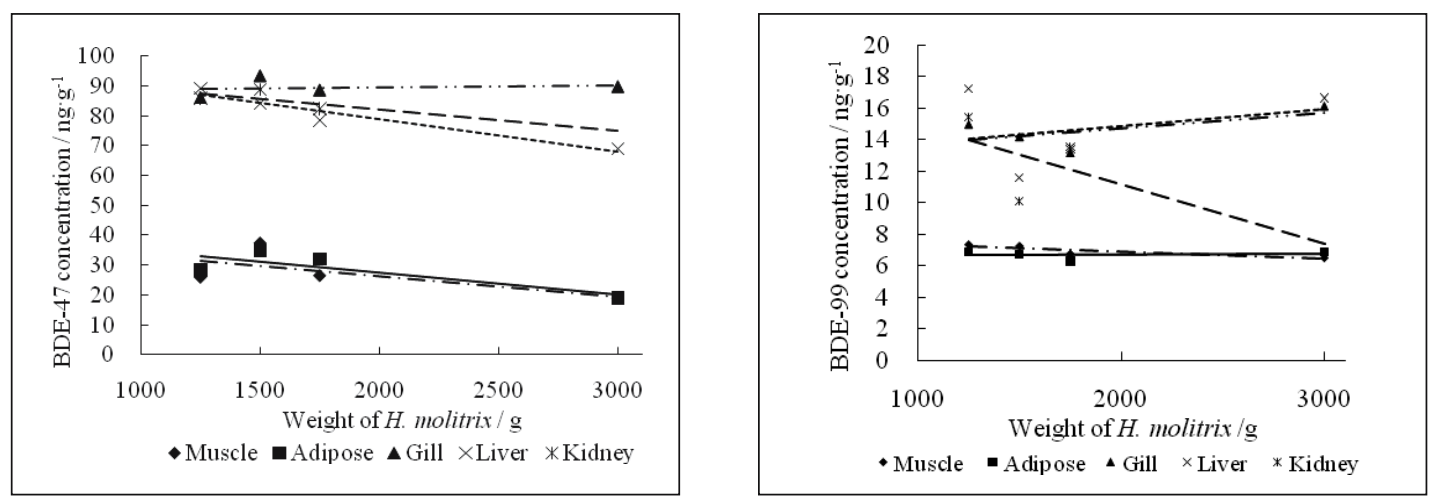

Fig. 5. BDE-47, -99 concentrations in five organs of three fishes with different sizes. Five tissues included muscle, adipose, gill, liver and kidney. (A) Fish size of Cyprinus carpio between 600-1000 g. (B) Fish size of Culter alburnus between 200-1000 g. (C) Fish size of Hypophthalmichthys molitrix

fish size. For example, BDE-47 concentration was constant in adipose tissue, muscle, and kidney, but was slightly positively correlated with fish size increasing in liver and gill of Cyprinus carpio (Fig. 5A). Interestingly, BDE-99 concentration was constant in adipose tissue, increased in muscle, and slightly decreased in liver, kidney, and gills. For Culter alburnus, BDE-47 concentrations were close to constant in adipose tissue, muscle, and gill, and slightly increased in liver and kidney (Fig. 5B). BDE-99 concentration was slightly increased in liver, and remained stable in other organs with fish size increasing. For Hypophthalmichthys molitrix, BDE-47 concentration slightly decreased in adipose tissue, muscle, liver and kidney and remained stable the gills (Fig. 5C). BDE-99 was constant in muscle and adipose tissue, slightly increased in liver and gills, and significantly decreased in the kidneys with fish size growth. Vives et al (2004) found that the concentrations of most PBDEs in liver were correlated with fish age, this cannot apply to muscles. There is also evidence that the age of fish (Weijs et al. 2009), ringed seal (Ikonomou et al. 2002) and sparrow hawk (Law et al. 2003) all influence biotransformation and concentration levels of PBDEs. These results almost certainly reflect the increase in the production and industrial usage of PBDEs worldwide. However, Waszak et al. (2012) found that there is no clear positive correlation between the PBDE 
concentrations and size or length suggesting that the fluxes of PBDEs are still not constant (Vives et al. 2004). This research showed that it should be treated differently to each congener, especially those typical ones that have higher pollution levels in environmental matrix when the relationship between distribution pattern in tissues and fish size was analyzed. Those discrepancies appeared to be correlated with the PBDEs pollution fluxes varying with the change of the year, varying lipid content, lipid composition, congener-specific physico-chemical properties and their metabolism divergences in fish tissues (Waszak et al. 2012).

\section{Conclusions}

41 PBDE congeners were analyzed in sediment and fish from Lake Chaohu in China. Ten of them were detected. BDE-47 concentration was found to be the highest one with $5.17 \mathrm{ng} / \mathrm{g}$ in sediment and $58.47 \mathrm{ng} / \mathrm{g}$ in fish. Compared with other regions in the world, the levels of PBDEs in Lake Chaohu appeared to be in moderate position. PBDEs in surface sediment were evenly distributed across the lake. This implied that the source of PBDEs might be air deposition, rather than being water-borne. Tissue distribution patterns of PBDEs in four fish species are similar, BDE-47 $>$ BDE-99 $>$ BDE-100 $>$ BDE-66 $>$ BDE-138> BDE-183> BDE-154 > BDE-153. BDE-47/99 ratio was found to be 5.4, which was a traditional value compared with other data detected elsewhere. The concentrations of all PBDE congeners detected in this study were higher in fish gills, livers, and kidneys than those in muscles and adipose tissues. Furthermore, it was found that PBDE congeners in different tissues and organs of the three fish species had some different distribution patterns with fish size growth. Those discrepancies may be correlated with the PBDEs pollution fluxes varying with time and their metabolism divergence in fish tissues.

\section{Acknowledgements}

The study was financially supported by the Special Program of Environmental Protection Commonweal Research Project (GYH5011001).

\section{References}

[1] Besis, A. \& Samara, C. (2012). Polybrominated diphenyl ethers (PBDEs) in the indoor and outdoor environments - A review on occurrence and human exposure, Environmental Pollution, 169, pp. 217-229.

[2] Binelli, A., Guzzella, L. \& Roscioli, C. (2008). Levels and congener profiles of polybrominated diphenyl ethers (PBDEs) in Zebra mussels (D. Polymorpha) from Lake Maggiore (Italy), Environmental Pollution, 153, pp. 610-617.

[3] Blais, J.M., Charpentie, S., Pick, F., Kimpe, L.E., St Amand, A. \& Regnault-Roger, C.M. (2006). Polybrominated diphenyl ether, organ chlorine pesticide and polychlorinated biphenyl concentrations in fish from lakes along an elevation transect in the French Pyrenees, Ecotoxicology and Environmental Safety, 63, pp. 91-99.

[4] BSEF (2004). Bromine science and environmental forum (http://www.dsef.com/(11.03.2015)).

[5] Chen, C.Y., Tien, C.J., Sun, Y.M., Hsieh, C.Y. \& Lee, Ch.Ch. (2013a). Influence of water quality parameters on occurrence of polybrominated diphenyl ether in sediment and sediment to biota accumulation, Chemosphere, 90 , pp. 2420-2427.

[6] Chen, S.J., Feng, A.H., He, M.J., Chen, M.Y., Luo, X.J. \& Mai, B.X. (2013b). Current levels and composition profiles of PBDEs and alternative flame retardants in surface sediments from the Pearl River Delta, southern China: Comparison with historical data, Science of The Total Environment, 444, pp. 205-211.

[7] Covaci, A., Bervoets, L., Hoff, P., Voorspoels, S., Voets, J., Van Campenhout, K., Blust, R. \& Schepens, P. (2005). Polybrominated diphenyl ethers (PBDEs) in freshwater mussels and fish from Flanders, Belgium, Journal of Environmental Monitoring, 7, pp. 132-136.

[8] Dallaire, R., Ayotte, P., Pereg, D., Dery, S., Dumas, P., Langlois, E. \& Dewailly, E. (2009). Determinants of plasma concentrations of perfluorooctanesulfonate and brominated organic compounds in Nunavik Inuit adults (Canada), Environmental Science and Technology, 43, pp. 3042-3046.

[9] de Wit, C.A. (2002). An overview of brominated flame retardants in the environment, Chemosphere, 46, pp. 583-624.

[10] Domingo, J.L. (2012). Polybrominated diphenyl ethers in food and human dietary exposure: A review of the recent scientific literature, Food and Chemical Toxicology, 50, pp. 238-249.

[11] Eljarrat, E., Labandiera, A., Marsh, G., Raldua, D. \& Barcelo, D. (2007). Decabrominated diphenyl ether in river fish and sediment samples collected downstream an industrial park, Chemosphere, 69, pp. 1278-1286.

[12] Erdgrul, Ö., Covaci, A. \& Schepens, P. (2005). Levels of organ chlorine pesticides, polybrominated biphenyl and polybrominated biphenyl ethers in fish species from Kahramanmaras, Turkey, Environment International, 31, pp. 703-711.

[13] Frederiksen, M., Vorkamp, K., Thomsen, M. \& Knudsen, L.E. (2009). Human internal and external exposure to PBDEs - A review of levels and sources, International Journal of Hygiene and Environmental Health, 212 , pp. 109-134.

[14] Guo, Y., Tang, H.L., Meng, X.Z., Mai, B.X. \& Zeng, Y.P. (2007). Tissue distribution of PBDEs in Mandarin Fish, Environmental Sciences, 28, pp. 2806-2810. 
[15] Hardy, M.L., Schroeder, R., Biesemeier, J. \& Manor, O. (2002). Prenatal oral (gavage) developmental toxicity study of decabromodiphenyl oxide in rats, International Journal of Toxicology, 21, pp. 83-91.

[16] Hale, R.C., La Guardia, M.J., Harvey, E.P., Mainor, T.M., Duff, W.H. \& Gaylor, M.O. (2001). Polybrominated diphenyl ether flame retardants in Virginia freshwater fishes (USA), Environmental Science and Technology, 35, pp. 4585-4591.

[17] Hale, R.C., La Guardia, M.J., Harvey, E., Gaylor, M.O. \& Mainor, M.T. (2006). Brominated flame retardant concentration and trends in abiotic media, Chemosphere, 64, pp. 181-186.

[18] He, M.J., Luo, X.J., Chen, M.Y., Sun, Y.X., Chen, S.J. \& Mai, B.X. (2012). Bioaccumulation of polybrominated diphenyl ethers and decabromodiphenyl ethane in fish from a river system in a highly industrialized area, South China, Science of The Total Environment, 419, pp. 109-115.

[19] Hermanussen, S., Matthews, V., Päpke, O., Limpus, C.J. \& Gaus, C. (2008). Flame retardants (PBDEs) in marine turtles, dugongs and seafood from Queensland, Australia Marine Pollution Bulletin, 57, pp. 409-418.

[20] Hites, R.A. (2004). Polybrominated diphenyl ethers in the environment and in people: a meta-analysis of concentrations, Environmental Science and Technology, 38, pp. 945-956.

[21] Hong, S.H., Kannan, N., Jin, Y., Won, J.H., Han, G.M. \& Shim, W.J. (2010). Temporal trend, spatial distribution, and terrestrial sources of PBDEs and PCBs in Masan Bay, Korea, Marine Pollution Bulletin, 60, pp. 1836-1841.

[22] Huwe, J.K., Hakk, H. \& Birnbaum, L.S. (2008). Tissue distribution of polybrominated diphenyl ethers in male rats and implications for biomonitoring, Environmental Science and Technology, 42, pp. 7018-7024.

[23] Huwe, J., Hakk, H. \& Lorentzsen, M. (2007). Bioavailability and mass balance studies of a commercial pentapbromodiphenyl ether mixture in male Sprague-Dawley rats, Chemosphere, 66, pp. 259-266.

[24] Ikonomou, M.G., Rayne, S. \& Addison, R.F. (2002). Exponential increase of the brominated flame retardants, polypbrominated diphenyl ethers, in the Canadian Arctic from 1981 to 2000, Environmental Science and Technology, 36, pp. 1886-1892.

[25] Jaraczewska, K., Lulek, J., Covaci, A., Voorspoels, S., Kaluba-Skotarczak, A., Drews, K. \& Schepens, P. (2006). Distribution of polychlorinated biphenyls, organochlorine pesticides and polybrominated diphenyl ethers in human umbilical cord serum, maternal serum and milk from Wielkopolska region, Poland, Science of The Total Environment, 372, pp. 20-31.

[26] Jin, J., Liu, W.Z., Wang, Y. \& Tang, X.Y. (2008). Levels and distributions of polybrominated diphenyl ethers in plant, shellfish and sediment samples from Laizhou Bay in China, Chemosphere, 71, pp. 1043-1050.

[27] Karpeta, A., Rak-Mardyła, A., Jerzak, J. \& Gregoraszczuk, E.L. (2011). Congener-specific action of PBDEs on steroid secretion, CYP17, 17 $\beta$-HSD and CYP19 activity and protein expression in porcine ovarian follicles, Toxicology Letters, 206, pp. 258-263.

[28] Kelly, B.C., Ikonomou, M.G., Blair, J. \& Gobas, F.A.P.C. (2008). Bioaccumulation behavior of polybrominated diphenyl ethers (PBDEs) in a Canadian Arctic marine food web, Science of The Total Environment, 401, pp. 60-72.

[29] Kemmlein, S., Herzke, D. \& Law, R.J. (2003). BFR-governmental testing programme, Environment International, 29, pp. 781-792.

[30] Labandeira, A., Eljarrat, E. \& Barcló, D. (2007). Congener distribution of polybrominated diphenyl ethers in feral carp (Crypinus carpio) from the Llobregat River, Spain Environmental Pollution, 146, pp. 188-195.

[31] Lavandier, R., Quinete, N., Hauser-Davis, A., Simões, Dias P., Taniguchi, S., Montone, R. \& Moreira, I. (2013). Polychlorinated biphenyls (PCBs) and polybrominated diphenyl ethers (PBDEs) in three fish species from an estuary in the southeastern coast of Brazil, Chemosphere, 90, pp. 2435-2443.

[32] Law, R.J., Alaee, M., Allchin, C.R., Boon, J.P., Lebeuf, M., Lepom, P. \& Stern, G.A. (2003). Levels and trends of polybrominated diphenylethers and other brominated flame retardants in wildlife, Environment International, 29, pp. 757-770.

[33] Law, R.J., Herzke, D., Harrad, S., Morris, S., Bersuder, P. \& Allchin, C.R. (2008). Levels and trends of HBCD and BDEs in the European and Asian environments, with some information for other BFRs, Chemosphere, 73, pp. 223-241.

[34] Liu, H.L, Hu, W., Sun, H., Shen, O.X., Wang, X.R, Lam, M.H.W., Giesy, J.P., Zhang, X.W. \& Yu, H.X. (2011). In vitro profiling of endocrine disrupting potency of 2,2an and tetrabromodiphenyl ether (BDE47) and related hydroxylated analogs (HO-PBDEs), Marine Pollution Bulletin, 63, pp. 287-296.

[35] Lorber, M. (2007). Exposure of Americans to polybrominated diphenyl ethers, Journal of Exposure Science and Environmental Epidemiology, 18, pp. 2-19.

[36] Mai, B.X., Chen, S.J., Luo, X.J., Yang, Q.S., Shen, G,Y., Peng, P.A., Fu, J.M. \& Zeng, E.Y. (2005). Distribution of polybrominated diphenyl ethers in sediments of the Pearl River Delta and adjacent South China Sea, Environmental Science and Technology, 39, pp. 3521-3527.

[37] Mariottini, M., Corsi, I., Torre, C.D., Caruso, T., Bianchini, A., Nesi, I. \& Focardi, S. (2008). Biomonitoring of polybrominated diphenyl ether (PBDE) pollution: A field study, Comparative Biochemistry and Physiology C, 148, pp. 80-86.

[38] Moon, H.B., Choi, M.K., Yu, J., Jung, R.H. \& Choi, H.G. (2012). Contamination and potential sources of polybrominated diphenyl ethers (PBDEs) in water and sediment from the artificial Lake Shihwa, Korea, Chemosphere, 88, pp. 837-843. 
[39] Peng, J.H., Huang, C.W., Weng, Y.M. \& Yak, H.K. (2007). Determination of polybrominated diphenyl ethers (PBDEs) in fish samples from rivers and estuaries in Taiwan, Chemosphere, 66, pp. 1990-1997.

[40] Petreas, M., Nelson, D., Brown, F.R., Goldberg, D., Hurley, S. \& Reynolds, P. (2011). High concentrations of polybrominated diphenylethers (PBDEs) in breast adipose tissue of California women, Environment International, 3, pp. 190-197.

[41] Roosens, L., Geeraerts, C., Belpaire, C., Van Pelt, I., Neels, H. \& Covaci, A. (2010). Spatial variations in the levels and isomeric patterns of PBDEs and HBCDs in the European eel in Flanders, Environment International, 36, pp. 415-423.

[42] Shen, M., Yu, Y., Zheng, G.J., Yu, H., Lam, P.K.S., Feng, J. \& Wei, Z. (2006). Polychlorinated biphenyls and polybrominated diphenyl ethers in surface sediments from the Yangtze River Delta, Marine Pollution Bulletin, 52, pp. 1299-1304.

[43] Sjödin, A., Hagmar, L., Klasson-Wehler, E., Bjork, J. \& Bergman, A. (2000). Influence of consumption of fatty Baltic Sea fish on plasma levels of halogenated environmental contaminants in Latvian and Swedish men, Environmental Health Perspectives, 108, pp. 35-41.

[44] Stapleton, H.M., Alaee, M., Letcher, R.J. \& Baker, J.E. (2004c). Debromination of the flame retardant decabromodiphenyl ether by juvenile carp (Cyprinus carpio) following dietary exposure, Environmental Science and Technology, 38, pp. 112-119.

[45] Stapleton, H.M. \& Dodder, N.G. (2008). Photodegradation of decabromodiphenyl ether in house dust by natural sunlight, Environmental Toxicology and Chemistry, 27, pp. 206-312.

[46] Stapleton, H.M., Letcher, R.J. \& Baker, J.E. (2004b). Debromination of polybrominated diphenyl ether congeners BDE 99 and BDE 183 in the intestinal tract of the common carp (Cyprinus carpio), Environmental Science and Technology, 38, pp. 1054-1061.

[47] Stapleton, H.M., Letcher, R.J., Li, J. \& Baker, J.E. (2004a). Dietary accumulation and metabolism of polybrominated diphenyl ethers by juvenile carp (Cyprinus carpio), Environmental Toxicology and Chemistry, 23, pp. 1939-1946.

[48] Tanabe, S., Ramu, K., Isobe, T. \& Takahashi, S. (2008). Brominated flame retardants in the environment of Asia-pacific: an overview of spatial and temporal trends, Journal of Environmental Monitoring, 10, pp. $188-197$.

[49] Verreault, J., Shahmiri, S., Gabrielsen, G.W. \& Letcher, R.J. (2007). Organ halogen and metabolically-derived contaminants and associations with whole body constituents in Norwegian Arctic glaucous gulls, Environment International, 3, pp. 823-830.

[50] Vives, I., Grimalt, J.O., Lacorte, S., Guillamon, M. \& Barcelo, D. (2004). Polybromodiphenyl ether flame retardants in fish from lakes in European high mountains and Greenland, Environmental Science and Technology, 38, pp. 2338-2344.

[51] Wang, Z., Ma, X.D., Lin, Z.S., Na, G.S. \& Yao, Z.W. (2009). Congener specific distributions of polybrominated diphenyl ethers (PBDEs) in sediment and mussel (Mytilus edulis) of the Bo Sea, China, Chemosphere, 74, pp. 896-901.

[52] Waszak, I., Dabrowska, H. \& Góra, A. (2012). Bioaccumulation of polybrominated diphenyl ethers (PBDEs) in flounder (Platichthys flesus) in the southern Baltic Sea, Marine Environmental Research, 79, pp. 132-141.

[53] Weijs, L., Dirtu, A., Das, K., Gheorghe, A., Reiknders, P.J.H., Neels, H., Blust, R. \& Covaci, A. (2009). Inter-species differences for polychlorinated biphenyls and polybrominated diphenyl ethers in marine top predators from Southern North Sea: Part 2. Biomagnifications in harbor seals and harbor porpoises, Environmental Pollution, 157, pp. 445-451.

[54] Xia, C.H, Lam, J.C.W., Wu, X.G, Sun, L.G, Xie, Z.Q. \& Lam, P. K.S. (2011). Levels and distribution of polybrominated diphenyl ethers (PBDEs) in marine fishes from Chinese coastal waters, Chemosphere, 82 , pp. 18-24.

[55] Xian, Q.M., Ramu, K., Isobe, T., Sudaryanto, A., Liu, X.H., Gao, Z.S., Takahashi, S., Yu, H.X. \& Tanabe, S. (2008). Levels and body distribution of polybrominated diphenyl ethers (PBDEs) and hexabromocyclododecanes (HBCDs) in freshwater fishes from the Yangtze River, China, Chemosphere, 71, pp. 268-276.

[56] Yogui, G.T. \& Sericano, J.L. (2009). Polybrominated diphenyl ether flame retardants in the U.S. Marine environment: A review, Environment International, 35, pp. 655-666.

[57] Zhao, X.R., Qin, Z.F., Yang, Z.Z., Zhao, Q., Zhao, Y.X., Qin, X.F., Zhang, Y.C., Ruan, X.L., Zhang, Y.F. \& Xu, X.B. (2010). Dual body burdens of polychlorinated biphenyls and polybrominated diphenyl ethers among local residents in an e-waste recycling region in Southeast China, Chemosphere, 78, pp. 659-666.

[58] Zhou, P., Lin, K.F, Zhou, X.Y,Zhang, W., Huang, K., Liu, L.L, Guo, J. \& Xu, F. (2012). Distribution of polybrominated diphenyl ethers in the surface sediments of the Taihu Lake, China, Chemosphere, 88, pp. 1375-1382. 